\title{
Dylematy bezpieczeństwa państw baltyckich po aneksji Krymu
}

\begin{abstract}
Streszczenie: Obawy o rewizjonistyczną politykę Rosji w regionie bałtyckim wzrosły w 2008 r. po konflikcie rosyjsko-gruzińskim. Jednak to aneksja Krymu i wojna we wschodniej Ukrainie spowodowała znaczący spadek poczucia bezpieczeństwa w regionie. Rosja postrzegana jest jako największe zagrożenie w regionie. Podczas gdy środki militarne budzą największy niepokój w państwach bałtyckich, Litwa, Łotwa i Estonia obawiają się także rosyjskiej presji na ich system polityczny, gospodarkę, kulturę, życie społeczne oraz tożsamość narodową. Poniższa praca będzie miała na celu wskazanie dynamiki dyskursu bezpieczeństwa w państwach bałtyckich w związku z wydarzeniami we wschodniej Ukrainie. Analiza będzie dotyczyła w szczególności odpowiedzi na pytania, w jaki sposób „kryzys ukraiński” wpłynął na postrzeganie bezpieczeństwa w państwach bałtyckich oraz jakie działania zostały podjęte na poziomie narodowym i regionalnym. Dodatkowo, zbadana zostanie relacja pomiędzy narodowymi a regionalnymi interesami w sferze bezpieczeństwa w państwach bałtyckich.
\end{abstract}

Słowa kluczowe: bezpieczeństwo, państwa bałtyckie, aneksja Krymu, Rosja

\section{Wprowadzenie}

Do upadku Związku Radzieckiego i wycofaniu wojsk sowieckich/rosyjskich z Litwy, Łotwy i Estonii, region bałtycki stał się jednym z najbardziej stabilnych w obszarze postsowieckim. Dzięki konsekwentnej drodze ku Europie oraz włączeniu w struktury europejskie i transatlantycki system bezpieczeństwa, państwa bałtyckie zostały objęte gwarancjami bezpieczeństwa umożliwiającymi ich dynamiczny rozwój. Jednak rewizjonistyczne ambicje Rosji w Europie Wschodniej, a zwłaszcza aneksja Krymu, spowodowały wzrost poczucia zagrożenia w państwach bałtyckich, które mogłyby stać się obszarem potencjalnego konfliktu militarnego między NATO a Rosją.

Aneksja Krymu przez Rosję wywołała ostrą reakcję ze strony państw bałtyckich. Wcześniej, Litwa, Łotwa i Estonia aktywnie wspierały pro- 
ces stowarzyszeniowy Ukrainy (wzmocnienie Partnerstwa Wschodniego w UE było jednym z priorytetów litewskiego przewodnictwa w Radzie Europejskiej UE w 2013 r.). Na szczycie Partnerstwa Wschodniego UE w 2013 r. w Wilnie Ukraina miała podpisać nową umowę o stowarzyszeniu z UE, jednak proces został zahamowany wydarzeniami w Kijowie. Po aneksji Krymu Litwa, Łotwa i Estonia popierały wprowadzenie sankcji UE na Rosję. Mimo, że odbiły się one niekorzystnie na ich gospodarkach, w dalszym ciągu są za ich utrzymaniem. Litwa deklarowała największe poparcie dla Ukrainy i podejmowała najbardziej zdecydowane działania wobec Rosji. Organizowała pomoc medyczną, wsparcie finansowe szkoleń wojskowych oraz dostawy amunicji dla Ukrainy (Dura, 2015), a w 2016 r. skrytykowała łamanie praw Tatarów krymskich przez Rosje (Litewski sejm..., 2016). Mieszkańcy państw bałtyckich solidaryzowali się z Ukrainą i manifestowali przeciwko Rosji, a w wielu miastach pomniki sowieckie zostały pomalowane ukraińskimi barwami narodowymi.

W środowisku międzynarodowym dostrzeżono wagę wyzwań i konieczność większej aktywności w regionie, celem zapobiegania potencjalnym zagrożeniom w Europie Wschodniej, oraz pogłębiono integrację w dziedzinie bezpieczeństwa. Widocznym efektem były zintensyfikowane działania NATO w regionie bałtyckim poprzez wzmocnienie wschodniej flanki oraz zaangażowanie UE w działania dotyczące ,miękkich” aspektów bezpieczeństwa, takich jak polityka informacyjna i medialna. Jednak „kryzys ukraiński” i pogorszenie relacji Rosji z państwami zachodnimi uwidoczniły różnice $\mathrm{w}$ percepcji bezpieczeństwa między państwami bałtyckimi (lub szerzej, w Europie Środkowo-Wschodniej) a Zachodem oraz między poszczególnymi państwami bałtyckimi. Wzrosło poczucie zagrożenia konfliktem militarnym na tym obszarze oraz świadomość elit politycznych Litwy, Łotwy i Estonii o konieczności przygotowania się na nowe wyzwania. Dodatkowo, zewnętrzna presja zmusiła państwa do aktywniejszej polityki obronnej. Litwa, Łotwa i Estonia uświadomiły sobie słabość ich dotychczasowych strategii narodowych, współpracy między nimi oraz w ramach różnych wielostronnych formatów. Dlatego w kontekście wydarzeń na Ukrainie państwa bałtyckie uaktualniły swoje polityki narodowe i podjęły współpracę na poziomie bilateralnymi, w ramach organizacji regionalnych, europejskich i międzynarodowych. Widocznym następstwem aneksji Krymu przez Rosję była próba pogłębienia współpracy państw bałtyckich i zorientowanie na rozwiązywaniu wspólnych problemów. W ostatnim czasie państwa bałtyckie koncentrowały swoje wysiłki na współpracy, zwłaszcza w kwestiach: militarnych, 
energetycznych i informacyjnych. Od kilku lat szczególną uwagę na Litwie, Łotwie i w Estonii poświęca się także cyber-bezpieczeństwu oraz integracji społecznej.

Celem przywództwa Władimira Putina jest nie tylko rywalizacja wojskowo-strategiczna, ale także realizacja projektu ,zbierania ziem rosyjskich" i odbudowy swojej pozycji mocarstwowej w obszarze postsowieckim (Zięba, 2014, s. 13-40). Koncepcja rewitalizacyjna Putina zakłada wykorzystanie środków militarnych, politycznych, gospodarczych (energetycznych), kulturowych i społecznych (Laurelle, 2015; Panova, 2015, s. 80-98). Podczas gdy środki militarne budzą największy niepokój w środowisku międzynarodowym, obecnie najbardziej efektywnym instrumentem jest sfera informacyjna. Poprzez działania propagandowe Rosja może dyskredytować państwa na arenie międzynarodowej, a wpływając na ich cyber-bezpieczeństwo destabilizować system polityczny. Dodatkowo, możliwość użycia przez Rosję surowców energetycznych jako narzędzia politycznego nacisku stała się zagrożeniem dla bezpieczeństwa energetycznego innych państw (Pacuła, 2013, s. 51-66). W ujęciu konfliktów asymetrycznych W. Gierasimowa, niemilitarne środki wpływu stają się bardziej efektywne niż tradycyjne działania militarne (Герасимов, 2013). W przypadku państw bałtyckich celem oddziaływania Rosji jest nawiązanie, utrzymanie lub rozszerzenie wielopoziomowych powiązań między Rosją a diasporą oraz wymuszenie określonych działań w polityce wewnętrznej państw bałtyckich. Dlatego Litwa, Łotwa i Estonia obawiają się rosyjskiej presji na ich system polityczny, życie społeczne i gospodarcze oraz tożsamość narodową.

Artykuł dotyczący dynamiki percepcji bezpieczeństwa Litwy, Łotwy i Estonii zorganizowany jest w następujący sposób. Pierwsza część będzie poświęcona sferze militarnej obejmującej politykę obronną państw bałtyckich oraz intensyfikację działań NATO w regionie. Następnie zostanie scharakteryzowana polityka bezpieczeństwa informacyjnego, w tym w zakresie przeciwdziałania dezinformacji i propagandzie rosyjskiej oraz alternatywnych źródeł informacji. Kolejna część będzie dotyczyła sekurytyzacji mniejszości narodowych w państwach bałtyckich oraz strategii integracyjnych wobec mniejszości. W czwartej części uwaga zostanie zwrócona na współpracę Litwy, Łotwy i Estonii w organizacjach trójstronnych, regionalnych oraz $\mathrm{z}$ ważniejszymi partnerami w kwestiach poprawy bezpieczeństwa narodowego i regionalnego. Poniższa praca będzie miała na celu wskazanie dynamiki dyskursu bezpieczeństwa w państwach bałtyckich w związku z wydarzeniami we wschodniej Ukrainie. 
Analiza będzie dotyczyła w szczególności odpowiedzi na pytania, w jaki sposób państwa bałtyckie postrzegają swoje bezpieczeństwo narodowe i regionalne oraz jakie metody i środki podejmują w celu ograniczania zagrożeń? W trakcie procesu badawczego zostaną zweryfikowane hipotezy dotyczące: 1) skali efektywności polityk narodowych; 2) poziomu współpracy państw bałtyckich w kontekście „kryzysu ukraińskiego”; a także 3) relacji (hierarchii) pomiędzy narodowymi a regionalnymi interesami w sferze bezpieczeństwa w państwach bałtyckich. Pozwoli to na wskazania uwarunkowań zewnętrznych i wewnętrznych wpływających na stabilność w regionie, zwłaszcza w kontekście agresywnej polityki Rosji.

\section{Państwa baltyckie jako obszar potencjalnego konfliktu militarnego}

Po odzyskaniu niepodległości przez państwa bałtyckie, ich relacje z Rosją układały się stosunkowo dobrze, chociaż nieraz dochodziło do konfliktów. W latach dziewięćdziesiątych wycofano wojska sowieckie/ rosyjskie z państw bałtyckich, co umożliwiło rozpoczęcie procesu negocjacyjnego oraz włączenie Litwy, Łotwy i Estonii do UE i NATO. W tym okresie Litwa, Łotwa i Estonia postrzegały swoją przyszłą geopolityczną rolę jako pomost pomiędzy NATO i Rosją. Okres relatywnej współpracy i neutralnych stosunków między państwami bałtyckimi a Rosją przerwała agresywna polityka Putina wobec państw Europy Środkowo-Wschodniej. Obawy o rewizjonistyczną politykę Rosji w regionie bałtyckim wzrosły w 2008 r. po konflikcie rosyjsko-gruzińskim. Jednak to aneksja Krymu i wojna we wschodniej Ukrainie spowodowała znaczący spadek poczucia bezpieczeństwa $\mathrm{w}$ regionie. W ostatnim czasie zanotowano wzrost aktywności rosyjskich statków wojennych i łodzi podwodnych w pobliżu morskich granic państw bałtyckich. Dochodziło także do przekraczania przestrzeni powietrznej przez rosyjskie samoloty i śmigłowce. Dodatkowo Rosja rozpoczęła wdrażanie szerokiego programu rozbudowy infrastruktury wojskowej w regionie. Siły zostały skoncentrowane w obwodzie kaliningradzkim. Zanotowano również zwiększenie aktywności militarnych na Białorusi (Piotrowski, Raś, 2016). Choć bezpośredni atak militarny ze strony Rosji oraz konflikt Rosja-NATO na obszarze państw bałtyckich wciąż jest uznawany za mało prawdopodobny, państwa podjęły działania w kwestii obronności i stabilności regionu. Wiązało się to z przekonaniem, że na agresora odstraszająco działa już sama gotowość do obrony. Ponieważ państwa bałtyckie dysponują niewielkim poten- 
cjałem militarnym i nie są zdolne do samodzielnej obrony (Szymański, 2015) po aneksji Krymu domagały się one od NATO wzmocnienia gwarancji bezpieczeństwa regionalnego. Wśród ekspertów nie było zgody, co do działań, które powinny być podjęte w celu zwiększenia bezpieczeństwa w regionie, aby reakcja NATO nie była uznana za prowokację i nie zintensyfikowała sił rosyjskich. Na szczycie NATO w Newport w 2014 r. zdecydowano o wzmocnieniu wschodniej flanki, poprzez utworzenie sił szybkiego reagowania tzw. „szpicy”. „Szpicę” miały tworzyć oddziały kilku tysięcy żołnierzy, gotowych do rozmieszczenia w dowolnym miejscu w ciagu kilku dni, przy wsparciu sił morskich, powietrznych albo specjalnych. Kwaterę główną szpicy NATO powołano w Polsce, a pozostałe kwatery - również na Litwie, Łotwie i Estonii (W Polsce..., 2014). Z kolei na szczycie w Warszawie w $2016 \mathrm{r}$. potwierdzono, że dodatkowe 4 bataliony bojowe wojsk NATO, po 1 tys. żołnierzy każdy, będą stacjonowały na Litwie, Łotwie, w Estonii i Polsce (Barnes, 2016). NATO zwiększyło częstotliwość ćwiczeń wojskowych w celu efektywnego reagowania na zmiany $\mathrm{w}$ sferze bezpieczeństwa $\mathrm{w}$ regionie. Oznacza to, że zarówno NATO, jak i Rosja demonstrują swoją gotowość do odparcia ewentualnej agresji (Zięba, 2015, s. 5-26). Dodatkowo, w 2013 r. Litwa otworzyła Centrum Bezpieczeństwa Energetycznego NATO, a w połowie 2014 r. powołano Centrum Komunikacji Strategicznej NATO w Rydze, które zajmie się rosyjskim soft power w przestrzeni komunikacyjnej.

Wydarzenia na Krymie i we wschodniej Ukrainie wpłynęły na rekonceptualizację polityk narodowych państw bałtyckich, zwłaszcza w kontekście polityki obronnej. Litwa i Łotwa przez lata przeznaczały niewielkie wydatki na obronę. Po kryzysie z 2008 r. Litwa obniżyła je do $0,8 \%$ PKB, a Łotwa - 0,9\% PKB. W 2014 r. z uwagi na obecną sytuację oba państwa zobowiązały się je podnieść do 2\% PKB w $2020 \mathrm{r}$. W $2016 \mathrm{r}$. wydatki na obronę Litwy wynosiły 1,49\% PKB, a Łotwy - 1,45\% PKB. Estonia przeznacza obecnie 2,16\% swojego PKB na obronę (Litwa..., 2016). Estonia jest jedynym spośród państw bałtyckich, które od momentu odzyskania niepodległości utrzymuje obowiązkową służbę wojskową (8 lub 11 miesięcy), za którą przemawiają wysokie poparcie społeczne oraz nieprzewidywalność działań Rosji. Litwa i Łotwa zrezygnowały z poboru (odpowiednio w 2008 r. i 2006 r.), jednak po aneksji Krymu zadecydowały o zwiększeniu liczby żołnierzy. W maju 2015 roku Litwa wznowiła pobór na okres 5 lat. Estonia rozpoczęła program rozbudowy i modernizacji sił zbrojnych, zmierzający do uzyskania nowych zdolności bojowych. Zgodnie z programem rozwoju systemu obrony narodowej 
Estonii na lata 2013-2022, siły zbrojne mają pozyskać szereg nowych typów uzbrojenia i sprzętu wojskowego, a liczebność estońskiej armii ulegnie zwiększeniu (Palowski, 2014). Przy wsparciu NATO oraz dzięki zwiększeniu wydatków na obronę państwa bałtyckie zwiększyły inwestycje w rozwój infrastruktury wojskowej i logistyki.

„Ukraiński scenariusz" dla państw bałtyckich jest mało wiarygodny. Wydaje się, że rosyjska presja na państwa bałtyckie to element gry psychologicznej, w której Rosja dąży do destabilizacji ich środowiska politycznego. Dla państw bałtyckich oznacza to konieczność adaptacji do różnych scenariuszy wojny hybrydowej. Militaryzacja regionu nie sprzyja ociepleniu relacji między Rosją a Litwą, Łotwą i Estonią. Wobec zamrożenia konfliktu we wschodniej Ukrainie i okupacji Krymu niezwykle trudno będzie Litwie, Łotwie i Estonii nawiązać bliższe stosunki ze swoim wschodnim sąsiadem.

\section{Walka z dezinformacją i przeciwdzialanie rosyjskiej propagandzie}

Mniejszości rosyjskojęzyczne żyjące w przestrzeni medialnej Rosji, czują się z nią związane, przejmują jej punkt widzenia, światopogląd i wartości. To rodzi niebezpieczeństwo dla spójności państw, w których przebywają (Kuczyńska-Zonik, 2016, s. 43-59). W mediach rosyjskich przekaz koncentruje się na dychotomii pomiędzy wartościami Zachodu i Rosji oraz wyjątkowości świata rosyjskiego (zgodnie z koncepcja Русский Мир). Dominuje negatywny obraz rządów państw bałtyckich (niedemokratyczne, antyrosyjskie, z tendencjami neonazizmu), krytyka obecności NATO $w$ regionie (NATO jako okupant) oraz nostalgia za okresem sowieckim. $Z$ powodu dezinformacji i propagandy w mediach Litwa i Łotwa kilkakrotnie ograniczały transmisję rosyjskojęzycznych kanałów telewizyjnych. Na Litwie w październiku 2013 r. ograniczono nadawanie rosyjskojęzycznej telewizji PBK, a w 2014 r. - RTR-Planeta oraz NTV-Mir. Przyczyną był fałszywy przekaz na temat roli Armii Sowieckiej w państwach bałtyckich w 1991 roku. W 2015 roku kanał RTR-Planeta został zawieszony na trzy miesiące $\mathrm{z}$ powodu propagowania nienawiści między narodem ukraińskim a rosyjskim. Obecnie, w parlamencie trwają prace nad ograniczeniem transmisji programów telewizyjnych (maksymalnie do 10\%) w językach innych niż oficjalne UE. W 2014 r., a następnie w kwietniu 2016 r., Łotwa nałożyła karę na Rosja-RTR z powodu mowy nienawiści i nawoływania do konfliktów et- 
nicznych (Latvia suspends..., 2016). Estonia nie wprowadziła ograniczeń rosyjskich przekazów wyrażając przekonanie, że wolność słowa należy do najważniejszych wartości, jednak w 2015 r. odmówiła przyjazdu włoskiego dziennikarza Gulietto Chiesa i jego udziału w spotkaniu klubu Impressum, organizowanego przez dziennikarzy powiązanych z rosyjskim dziennikiem „Komsomolskya Pravda”. Chiesa znany był z kontrowersyjnych wypowiedzi na temat polityki Rosji, popierał rosyjskie zaangażowanie w Gruzji oraz aneksję Krymu (Italian..., 2014).

Chociaż już wcześniej podejmowano próby walki z rosyjską propagandą ${ }^{1}$ aneksja Krymu i wojna na Ukrainie uświadomiły państwom bałtyckim brak wspólnej i konsekwentnej polityki medialnej zapobiegającej propagandzie rosyjskiej. Dlatego podjęto działania na rzecz poprawy ich bezpieczeństwa informacyjnego, opierając się na czterech zasadach: podnoszenia świadomości, asertywności, alternatywy i odpowiedzialności (Maliukevičius, 2015, s. 32-43). Państwa bałtyckie pracowały nad uatrakcyjnieniem własnej oferty medialnej, podnoszeniem jakości mediów oraz propagowaniem postaw obywatelskich. $\mathrm{Na}$ Litwie zainaugurowano program warsztatowy dla dziennikarzy posługujących się językiem rosyjskim, którego celem jest tworzenie otwartego, dojrzałego, niezależnego środowiska medialnego w państwach bałtyckich (US Embassy). Państwa bałtyckie poparły także propozycję utworzenia europejskiego rosyjskojęzycznego kanału telewizyjnego, który miałby być alternatywą dla programów telewizyjnych z Rosji (Latvia proposes..., 2015). Jednak do tej pory jedynie Estonia zdecydowała się na wprowadzenie platformy rosyjskojęzycznej do swojej oferty medialnej. We wrześniu 2015 r. oficjalnie rozpoczęła nadawanie państwowa rosyjskojęzyczna telewizja $\mathrm{ETV}+$. W ten sposób próbowano osłabić wpływ mediów rosyjskich na rosyjskojęzyczną mniejszość zamieszkującą Estonię. Chociaż na razie nie można ocenić jej efektywności, trudno jej będzie konkurować z telewizją transmitowaną z Rosji, która cieszy się dużą popularnością i oglądalnością. W rosyjskojęzycznych mediach w Estonii mniej czasu poświęca się sprawom rosyjskim, czy relacji Estonii z Rosją. Problematyczna wydaje się sama funkcja ETV+. Kanał miał rzetelnie dostarczać wiedzy, informować oraz wspomagać instytucje państwowe w kształtowaniu postaw szacunku i tolerancji wobec obywateli bez względu na narodowość,

${ }^{1}$ Raporty dotyczące skali dezinformacji, propagandy i informacyjnego wpływu Rosji w państwach bałtyckich publikowały łotewski think-thank Re:Baltica, instytucje rządowe w Estonii (Kaitsepolitseiamet, KaPo) i na Litwie (Lietuvos Respublikos valstybes saugumo departamento, VSD). 
a także stymulować wzrost świadomości państwowej, tymczasem stał się narzędziem przeciwdziałania rosyjskiej propagandzie. Warto zaznaczyć, że postrzeganie mediów jako narzędzie w walce informacyjnej sprzyja podziałom społecznym i wzajemnej nieufności.

\section{Bezpieczeństwo społeczne i mniejszości narodowe i etniczne w państwach baltyckich}

Aneksji Krymu i wojna we wschodniej Ukrainie znacząco wpłynęły na postrzeganie bezpieczeństwa w regionie, a kwestia stabilności wewnętrznej i integracji społecznej stała się bardziej aktualna. Tuż po aneksji Krymu pojawiły się przypuszczenia, że „ukraiński scenariusz” może spotkać państwa bałtyckie, ze względu na problemy integracyjne mniejszości rosyjskojęzycznych, głównie na Łotwie i w Estonii oraz pozostawanie mniejszości $\mathrm{w}$ rosyjskiej sferze informacyjnej. Władze państw zdały sobie sprawę, że podziały społeczne mogą być wykorzystane przez Rosję jako kolejny instrument w wojnie hybrydowej przeciw państwom bałtyckim. Badania opinii publicznej wskazuja, że członkowie mniejszości narodowych są lojalni wobec państwa, w którym mieszkają. Obecnie, potencjał organizowania protestów i masowych demonstracji w obronie szkolnictwa czy symboli mniejszości jest dużo mniejszy niż w przeszłości, mimo tych samych żądań. Mniejszości narodowe postrzegane są jednak jako źródło destabilizacji. To oni mają największe problemy integracyjne, które związane są ze słabą znajomością języka państwowego (głównie na Łotwie i w Estonii). To z kolei implikuje ich słabą pozycję na rynku pracy, niski status społeczny oraz podatność na hasła populistyczne (Societal..., 2016).

W połowie 2015 r. na Litwie powołano Departament Mniejszości Narodowych (DMN) Litwy, który zastapił zlikwidowany w 2010 r. Departament Mniejszości Narodowych i Wychodźstwa (DMNiW) (EFHIR..., 2014). Przedstawiono Strategiczny Plan Działania (2016-2018), w którym za główne cele uznano: 1) integrację mniejszości etnicznych w społeczeństwie litewskim przy zachowaniu tożsamości narodowej i etnicznej, 2) tolerancję i brak dyskryminacji oraz 3 ) promocję różnorodności etnicznej i kulturowej (Tautiniu..., 2016). W tym samym czasie na niektórych ulicach w Wilnie pojawiły się tabliczki z podwójnymi nazwami (w języku litewskim i m.in. polskim, rosyjskim, niemieckim, angielskim), pełniące rolę dekoracyjną i informujące o wielokulturowym potencjale miasta 
(Dwujęzyczne..., 2017). Ponadto, w ramach walki z rosyjską propagandą informacyjną, państwowa spółka Centrum Litewskiego Radia i Telewizji (Telecentrum) przygotowała projekt nadawania polskich telewizji na Litwie (Radczenko, Kozicz, 2017).

W Estonii zliberalizowano ustawę o obywatelstwie. W latach 2014 2015 estoński parlament (Riigikogu) wprowadził liczne poprawki ułatwiające uzyskanie obywatelstwa dla uczniów, osób niepełnosprawnych oraz osób starszych powyżej 65. roku życia. Od stycznia 2016 r. estońskie obywatelstwo nadawane jest automatycznie od urodzenia dzieciom, których rodzice nie posiadają obywatelstwa oraz dzieciom poniżej 15. roku życia urodzonym w Estonii (Amnesty...). Dodatkowo, został zniesiony pisemny egzamin z języka państwowego na poziomie komunikatywnym dla osób powyżej 65 lat. Osobom niepełnoletnim umożliwiono posiadanie podwójnego obywatelstwa, pod warunkiem wyboru jednego z nich po osiągnięciu 21 lat (Hyndle-Hussein, 2015a). Podobne, choć kosmetyczne poprawki w ustawie o obywatelstwie wprowadzono także na Łotwie (Basic...). Automatyczne obywatelstwo na Łotwie jest wciąż mało prawdopodobne.

Z drugiej strony w państwach bałtyckich pojawiły się zachowania ksenofobiczne i nacjonalistyczne wśród elit politycznych i większości narodowej, które w negatywnym świetle stawiały mniejszości rosyjskojęzyczne lub je deprecjonowały. W ramach antyrosyjskich sankcji, Łotwa wstrzymała organizację cieszącego się ogromną popularnością rosyjskojęzycznego festiwalu artystycznego „Nowa Fala” (ros. Новая волна) ${ }^{2}$ w Jurmali i zakazała wjazdu na teren państwa artystom rosyjskim, którzy aktywnie popierali aneksję Krymu przez Rosję (Латвия..., 2014). Od początku 2017 r. obowiązują przepisy umożliwiające zwolnienie nielojalnych wobec państwa nauczycieli. Zmiany w ustawie o edukacji miały głównie na celu ograniczyć wpływ Rosji w rosyjskojęzycznych szkołach na Łotwie (Russia..., 2016).

Wewnątrz społeczeństw i reprezentujących ich interesy partii politycznych w państwach bałtyckich widoczna jest polaryzacja stanowisk - od skrajnie nacjonalistycznych po prorosyjskie, co utrudnia wypracowywanie jednolitej polityki zarówno poszczególnych państw, jak i całego regionu (Hyndle-Hussein, 2015b). Nowe polityki integracyjne wobec mniejszości nie oznaczają zmiany punktu widzenia Litwy, Łotwy i Estonii na sprawy mniejszości narodowych i etnicznych, więc nie należy

${ }^{2}$ Festiwal organizowano corocznie od 2002 r. W 2015 r. z powodu napiętych stosunków rosyjsko-łotewskich festiwal przeniesiono do Soczi. 
przypuszczać trwałego zwrotu w polityce narodowościowej tych państw. Należy ją traktować raczej jako konkretyzację lub aktualizację polityki narodowościowej w kontekście współczesnych wyzwań. Aneksja Krymu i wojna na Ukrainie istotnie ograniczyły poczucie bezpieczeństwa w regionie, nie wpłynęły jednak istotnie na dyskurs narodowościowy w tych państwach.

\section{Wspólpraca regionalna i międzynarodowa}

Widocznym następstwem aneksji Krymu przez Rosję była próba pogłębienia współpracy państw bałtyckich i zorientowanie na rozwiązywanie wspólnych problemów. Oprócz pogłębiania relacji ze wschodnimi sąsiadkami UE (Białorusią, Ukrainą, Gruzją) w ramach Partnerstwa Wschodniego, państwa bałtyckie współpracują w formatach trójstronnych, w Zgromadzeniu Bałtyckim (ZB) (na poziomie rządowym i parlamentarnym) oraz Bałtyckiej Radzie Ministrów (BRM) (na poziomie ministerialnym) w sferach: obronnej, gospodarczej i energetycznej, w tym alternatywnego zaopatrzenia w zasoby energetyczne, tworzenia wspólnego rynku energii elektrycznej oraz gazu ziemnego.

W obliczu wzrostu kosztów importu surowców energetycznych oraz nieprzewidywalności $\mathrm{w}$ relacjach $\mathrm{z}$ Rosja, państwa bałtyckie podjęły wysiłki na rzecz poprawy ich sytuacji energetycznej. Wyrazem tego był regionalny projekt budowy elektrowni jądrowej Visaginas na Litwie. Celem projektu miało być uniezależnienie od dostaw energii elektrycznej z Rosji. W marcu 2014 r., w związku z aneksją Krymu przez Rosję, siedem partii politycznych na Litwie podpisało porozumienie dotyczące głównych linii polityki bezpieczeństwa państwa do 2020 r., w tym polityki energetycznej (Partie..., 2014). W dokumencie znalazło się potwierdzenie chęci działań uniezależniających Litwę od dostaw rosyjskiej energii elektrycznej i kontynuacji synchronizacji z europejskim rynkiem energetycznym. Potwierdzono również potrzebę strategicznego partnerstwa energetycznego w regionie i koncepcję Visaginas. Litwa, uzależniona od dostaw surowców energetycznych od Rosji w największym stopniu spośród trzech państw bałtyckich, zainteresowana była projektami zwiększającymi jej bezpieczeństwo energetyczne. Dlatego inicjowała i intensyfikowała kooperację w formacie trójstronnym oraz z Polską. Estonia, której sytuacja energetyczna jest najlepsza (głównie dzięki produkcji energii z oleju łupkowego oraz odnawialnym źródłom energii) (Kama, 
2016, s. 831-856), preferowała współpracę z Finlandią (budowa międzysystemowego połączenia gazowego Balticconector). Ostatecznie, z powodu wysokich kosztów oraz rozbieżnych interesów narodowych projekt Visaginas został zawieszony.

Istotną uwagę państwa bałtyckie poświęcają także przeciwdziałaniu dezinformacji i fałszowaniu informacji na temat II wojny światowej i okresu sowieckiego przez Rosję. W listopadzie 2015 r. w Rydze ministrowie sprawiedliwości Litwy, Łotwy i Estonii podpisali memorandum, domagając się odpowiedzialności od Rosji - spadkobierczyni ZSRR, i przyznania się do „okupacji” republik oraz przymusowego włączenia do ZRSS (Joint Declaration of the Ministers..., 2015). O ile jednak Estonia uważała memorandum za akt polityczny, Litwa i Łotwa wyraźnie żądały zadośćuczynienia za poniesione straty. Ostrą reakcję Litwy, Łotwy i Estonii wywołała także seria pamiątkowych monet z kolekcji „Miasta - stolice państw wyzwolone przez wojska sowieckie od okupantów niemiecko-faszystowskich", wypuszczonych w sierpniu 2016 r. przez Centralny Bank Federacji Rosyjskiej. Na rewersie znalazły się miasta - stolice państw europejskich „wyzwolonych” przez ZSRR w czasie II wojny światowej, a wśród nich Wilno, Ryga i Tallin (Центральный...). Dla Rosji, celebracja zwycięstwa w II wojnie światowej to sprawa honoru, reputacji i pozycji międzynarodowej. Polityka historyczna jest istotnym instrumentem realizacji jej interesów narodowych, obejmujących szeroko pojętą rosyjską strefę wpływów. Rosyjska polityka historyczna wobec Litwy, Łotwy i Estonii to konsekwencja ich niezależności i odpowiedź na niekorzystną sytuację mniejszości rosyjskojęzycznej w regionie.

Strategia bezpieczeństwa Litwy, Łotwy i Estonii zakłada kooperację tych państw z północno-zachodnimi sąsiadami, czego dowodem jest wieloletnia współpraca w obszarach gospodarki, polityki, kultury i bezpieczeństwa. Wśród istotnych przykładów zinstytucjonalizowanej nordycko-bałtyckiej współpracy należy wymienić porozumienie NB8 (pięć państw nordyckich i trzy bałtyckie), Nordycką Grupę Bojowej (Nordic Battle Group, NBG) czy Nordic Defense Cooperation (NORDEFCO) (Banaś, 2016, s. 201-217). Udział państw bałtyckich ma zwiększyć ich potencjał obronny, zdolności operacyjne i sprawność bojową jak również podnieść efektywność ich polityk bezpieczeństwa cywilnego, cybernetycznego i energetycznego. Narodowe zespoły szybkiego reagowania na zagrożenia cybernetyczne CERT (Computer Emergency Response Team) w państwach bałtyckich współpracują z CERT w państwach nordyckich na poziomie technicznym. Bezpieczeństwo cybernetyczne było także 
jednym z priorytetów estońskiego przywództwa grupie NB8 w 2014 r. (Pernik, Maldre, 2015, s. 44-52).

23 sierpnia 2016 r. państwa wzmocniły współpracę z USA w dziedzinie militarnej, potwierdzając, że NATO i USA są podstawowymi gwarantami bezpieczeństwa i stabilności w regionie państw bałtyckich (Joint Declaration on Increased...). Litwa, Łotwa i Estonia współpracują z USA w sferze bezpieczeństwa cybernetycznego, czego przykładem jest projekt Baltic Ghost, którego celem jest wymiana doświadczeń, informacji i reagowanie na cyber-zagrożenia. Ścisła kooperacja z USA realizowana jest także poprzez bilateralne stosunki amerykańsko-litewskie, amerykańskołotewskie i amerykańsko-estońskie, w których państwa zacieśniają relacje w różnych obszarach bezpieczeństwa.

Bliskim sojusznikiem Litwy, Łotwy i Estonii w Europie ŚrodkowoWschodniej jest Polska, która na arenie UE prezentuje podobne spojrzenie na Rosję i politykę wschodnią Unii, czego przykładem była jednogłośność i solidarność wobec polityki sankcji wobec Rosji. W 2016 r. powołana została trójnarodowa brygada LITPOLUKRBRIG, składająca się z batalionów z Polski, Litwy i Ukrainy. Dowództwo mieści się w Lublinie, a celem jest zacieśnienie regionalnej współpracy wojskowej i pomoc Ukrainie w reformowaniu jej sił zbrojnych. Litwa i Łotwa pogłębiały relacje z Polską i Szwecją w obszarze energetycznym (m.in. budowa mostów energetycznych Lit-Pol Link 2, połączenie elektroenergetyczne NordBalt oraz gazowe połączenie międzysystemowe Polska-Litwa GIPL). Polska wsparła również Litwę wydając oświadczenie o tym, że nie będzie kupowała energii elektrycznej z elektrowni atomowej w Ostrowcu na Białorusi.

\section{Podsumowanie}

Państwa bałtyckie reprezentują podobny stosunek do Rosji, warunkowany położeniem geopolitycznym czy wspólnymi doświadczeniami historycznymi. Dlatego wydawać by się mogło, że aneksja Krymu i wojna na Ukrainie zbliżyła trzy państwa bałtyckie w kwestii poczucia zagrożenia ze strony Rosji. Jednak Litwa, Łotwa i Estonia postrzegają swoje bezpieczeństwo w sposób zróżnicowany. Różnice polegają nie tylko w interpretacji zagrożeń, ale również skali zaangażowania w pomoc Ukrainie, metod i działań na rzecz bezpieczeństwa oraz stosunków z Rosją. 
Litwa, podobnie jak Polska, otwarcie krytykuje Rosję i podejmuje najbardziej stanowcze działania wobec wschodniego sąsiada (Raik, 2015, s. 16-22). W dokumencie litewskich służb specjalnych (VSD) i Ministerstwa Obrony Narodowej z 2017 r. Rosja oraz pozostająca pod jej wpływem Białoruś, zostały wymienione jako najpoważniejsze źródła zagrożeń dla bezpieczeństwa Litwy (szpiegostwo, służby wywiadowcze, polityka energetyczna, w tym budowa elektrowni jądrowej w Ostrowcu na Białorusi i w Kaliningradzie, wpływ informacyjny, propaganda, cyber-ataki oraz podżeganie do waśni między grupami etnicznymi). W litewskim dyskursie bezpieczeństwa dominują zagrożenia militarne (np. manewry woskowe Zapad 2017 jesienią 2017 r.) oraz obawa o przeprowadzenie ataku przez Rosję na państwa bałtyckie w ciagu 24-48 godzin (National..., 2017). Strach przed Rosją obecny jest nie tylko w debacie elit politycznych, ale również w opinii społecznej. Według Spinter tyrimai, w 2014 r. 55\% respondentów (niezależnie od narodowości) uznało, że państwom bałtyckim grozi niebezpieczeństwo ze strony Rosji (wojna ekonomiczna, zależność energetyczna, wojna informacyjna, możliwość wprowadzenia rosyjskich wojsk na Litwe, ruchy separatystyczne) (Ponad...). Nieco inne podejście do Rosji charakteryzuje Łotwę i Estonię, a zaangażowanie obu państw w pomoc Ukrainie było także mniejsze niż w przypadku Litwy. Estonia, podobnie jak państwa nordyckie opowiada się za współpracą w relacjach z Rosją oraz unikaniem krytyki i konfliktów. Dominuje przekonanie, że atak militarny Rosji w regionie jest mało prawdopodobny (President..., 2017). W Estonii 64\% badanych odpowiedziało, że migracja jest obecnie poważniejszym zagrożeniem niż agresja ze strony Rosji (Survey..., 2016). Łotwa reprezentuje podobne do Estonii adaptacyjne podejście w relacjach z Rosją.

W analizie ustalono, że poczucie zagrożenia ze strony Rosji w małym stopniu przyczyniło się do intensyfikacji współpracy trójstronnej między Litwą, Łotwą i Estonią. Państwa bałtyckie pogłębiły współpracę w obszarach dotyczących polityki obronnej, walki z dezinformacją, rosyjską propagandą i cyber-zagrożeniami. Podjęto starania na rzecz poprawy bezpieczeństwa energetycznego w regionie. Jednak realizacja wspólnego przedsięwzięcia energetycznego przez państwa bałtyckie - bez pomocy zagranicznych podmiotów - okazała się niezwykle trudna ze względu na wysokie koszty i rozbieżne interesy narodowe. Chociaż państwa bałtyckie łączy bliskość geograficzna, doświadczenia historyczne czy powiązania z Rosją, ograniczenia finansowe i różne priorytety narodowe lub wzajemna nieufność były barierą dla współpracy Litwy, Łotwy i Estonii. 
Podczas gdy Litwa, Łotwa i Estonia artykułowały swoje interesy na forum NATO i UE, w regionalnych i trilateralnych organizacjach wykazywały niską aktywność (Auers, 2015, s. 195-228). Pomimo nielicznych przykładów wydaje się, że interesy poszczególnych państw różnią się w znacznym stopniu, a udział w organizacjach regionalnych ma charakter spotkań i dyskusji, a nie realnych działań ukierunkowanych na rozwiązywanie wspólnych problemów. Powyższa argumentacja wskazuje także na wyższość interesów narodowych nad regionalnymi w kwestii bezpieczeństwa. Różnice w postrzeganiu bezpieczeństwa uniemożliwiają lub ograniczają państwom bałtyckim podjęcie efektywnej współpracy. Przypuszcza się, że państwa będą kontynuowały dotychczasowe kierunki współpracy z silniejszymi partnerami północnoeuropejskimi czy środkowoeuropejskimi kosztem współpracy w formacie trójstronnym.

Agresja rosyjska na Ukrainę, zwłaszcza na tle doświadczeń historycznych regionu, wpłynęła na poczucie zagrożenia ze strony Rosji w państwach bałtyckich, ale również w państwach Europy ŚrodkowoWschodniej i państwach nordyckich. Dlatego naturalne wydaje się poszukiwanie sojuszników wśród najbliższych sąsiadów podzielających ich opinie i przekonania oraz zacieśnienie kontaktów. Jednym z ważniejszych sojuszników państw bałtyckich jest Polska, jednak istotnym elementem osłabiającym integrację $\mathrm{w}$ regionie bałtyckim jest spór polsko-litewski wokół kwestii mniejszości polskiej na Litwie (Tymul, 2015, s. 119-135). Bliższa współpraca polityczna, obronna, ekonomiczna i energetyczna z Litwą, Łotwą i Estonią może zapewnić Polsce sojuszników skłonnych do popierania polskich inicjatyw na forach organizacji międzynarodowych i międzyrządowych. Tym samym państwom bałtyckim zapewni wsparcie dla ich projektów przeciwko oddziaływaniu Rosji w regionie.

\section{Bibliografia}

Amnesty International Report 2015/2016, https:/www.amnesty.org/en/countries/europe-and-central-asia/estonia/report-estonia/, 20.08.2016.

Auers D. (2015), Comparative Politics and Government of the Baltic States Estonia, Latvia and Lithuania in the $21^{s t}$ Century, Palgrave Macmillan, Nowy Jork.

Banaś M. (2016), Bezpieczeństwo państw baltyckich z perspektywy nordyckiej, „Rocznik Instytutu Europy Środkowo-Wschodniej”, nr 14, z. 5.

Barnes J. E. (2016), NATO Secretary-General Jens Stoltenberg Welcomes Increase in Military Spending by Europe and Canada, „The Wall Street Journal”, 13.06.2016, https://www.wsj.com/articles/nato-secretary-general-jens-stol- 
tenberg-welcomes-increase-in-military-spending-by-europe-and-canada-1465836063, 14.06.2016.

Basic facts about citizenship and language policy of Latvia and some sensitive history-related issues, Ministry of Foreign Affairs of the Republic of Latvia, http://www.mfa.gov.lv/en/policy/society-integration/citizenship-in-latvia/citizenship-policy-in-latvia/basic-facts-about-citizenship-and-language-policyof-latvia-and-some-sensitive-history-related-issues, 10.04.2017.

Dura M. (2015), Litwa i Ukraina wzmacniaja wspótprace wojskowa, 24.10.2015, Defence24, http://www.defence24.pl/267456, litwa-i-ukraina-wzmacniajawspolprace-wojskowa, 4.10.2017.

Dwujęzyczne tabliczki w Wilnie zostaja (2017), 15.02.2017, Wilnoteka, http://www. wilnoteka.1t/pl/artykul/dwujezyczne-tabliczki-w-wilnie-zostaja, 15.02.2017.

EFHR: Departament ds. Mniejszości Narodowych nie może być instytucja marionetkowa (2014), 12.11.2014, Znad Wilii, http://zw.lt/wilno-wilenszczyzna/efhrdepartament-ds-mniejszosci-narodowych-nie-moze-byc-instytucja-marionetkowa, 12.06.2016.

Hyndle-Hussein J. (2015a), Estonia nowelizuje ustawę o obywatelstwie, 28.01.2015, „Analizy OSW”, https://www.osw.waw.pl/pl/publikacje/analizy/2015-01-28/ estonia-nowelizuje-ustawe-o-obywatelstwie, 10.12.2016.

Hyndle-Hussein J. (2015b), Państwa bałtyckie wobec konfliktu na Ukrainie, 23.01.2015, „Komentarze OSW”, https://www.osw.waw.pl/pl/publikacje/komentarze-osw/2015-01-23/panstwa-baltyckie-wobec-konfliktu-na-ukrainie, 24.03.2017.

Italian journalist Chiesa ordered to leave Estonia (2014), 16.12.2014, Postimees, http://news.postimees.ee/3028421/italian-journalist-chiesa-ordered-to-leaveestonia, 22.12.2015.

Joint Declaration of the Ministers of Justice of the Baltic States (2015), 5.11.2015, http://www.just.ee/sites/www.just.ee/files/news-related-files/declaration_05_11_15_.pdf, 4.04.2017.

Joint Declaration on Increased Security and Defense Cooperation between the United States, Estonia, Latvia, and Lithuania, The White House, https://obamawhitehouse.archives.gov/the-press-office/2016/08/23/joint-declaration-increasedsecurity-and-defense-cooperation-between, 26.03.2017.

Kama K. (2016), Contending Geo-Logics: Energy Security, Resource Ontologies, and the Politics of Expert Knowledge in Estonia, „Geopolitics”, vol. 21, issue 4, http://dx.doi.org/10.1080/14650045.2016.1210129.

Kuczyńska-Zonik A. (2016), Russian propaganda-methods of influence in the Baltic States, „Yearbook of the Institute of East-Central Europe”, vol. 14, issue 2.

Laruelle M. (2015), The 'Russian World'. Russia's Soft Power and Geopolitical Imagination, Center on Global Interests.

Latvia proposes 'alternative' to Russian TV propaganda (2015), 8.01.2015, Euractiv, http://www.euractiv.com/sections/global-europe/latvia-proposes-alternativerussian-tv-propaganda-311109, 1.12.2015. 
Latvia suspends Rossiya RTR channel (2016), 7.04.2016, Lsm.lv, http://www.lsm. lv/en/article/societ/society/latvia-suspends-rossiya-rtr-channel.a177088/, 10.04.2017.

Litewski sejm w obronie krymskich Tatarów (2016), 12.04.2016, Wilnoteka.lt, http:// www.wilnoteka.lt/pl/artykul/litewski-sejm-w-obronie-krymskich-tatarow, 16.08.2016.

Litwa w pierwszej dziesiatce NATO pod względem finansowania obrony kraju (2016), 5.07.2016, Delfi.lt, http://pl.delfi.lt/aktualia/litwa/litwa-w-pierwszej-dziesiatcenato-pod-wzgledem-finansowania-obrony-kraju.d?id=71728496, 16.08.2016.

Maliukevičius N. (2015), The Roots of Putin's Media Offensive in the Baltic States: Learning Lessons in Counterstrategies, w: Baltic Visions: European Cooperation, Regional Stability, red. K. Redłowska, Foundation Institute for Eastern Studies, Warszawa.

National Security Threat Assessment (2017), State Security Department of the Republic of Lithuania (VSD), Second Investigation Department under the Ministry of National Defence (AOTD), Wilno.

Pacuła P. (2013), Współpraca obronna w regionie Morza Bałtyckiego. Stan obecny i perspektywy, „Bezpieczeństwo Narodowe”, nr 26/II.

Palowski J. (2014), Estonia rozbudowuje armię $i$ zwiększa wydatki na obronę narodo$w q, 10.04 .2014$, Defense24, http://www.defence24.pl/analiza_estonia-rozbudowuje-armie-i-zwieksza-wydatki-na-obrone-narodowa, 15.08.2016.

Panova V. V. (2015), Russia's 'Soft' Policies towards the Baltic States: The different faces of 'Soft Power, w: The Baltic States and Eastern Neighborhood between Russia and the UE, Latvian Institute of International Affairs, Ryga.

Partie porozumiaty się $w$ sprawie polityki bezpieczeństwa i obronności (2014), 29.03.2014, Znad Wilii, http://zw.lt/litwa/partie-porozumialy-sie-w-sprawiepolityki-bezpieczenstwa-obronnosci/, 10.04.2017.

Pernik P., Maldre P. (2015), Rising Challenges: Cybersecurity in the Baltic Sea Region, w: Baltic Visions: European Cooperation, Regional Stability, red. K. Redłowska, Foundation Institute for Eastern Studies, Warszawa.

Piotrowski M. A, Raś K. (2016), Wzrost zagrożenia rosyjskiego w raportach bałtyckich służb specjalnych, „Biuletyn PISM”, nr 44 (1394), https://www.pism.pl/ files/?id_plik=22127, 15.08.2016.

Ponad połowa Litwinów jest przekonana, że Rosja stanowi niebezpieczeństwo dla Litwy, 28.10.2014, Delfi.lt, http://pl.delfi.lt/aktualia/litwa/ponad-polowalitwinow-jest-przekonana-ze-rosja-stanowi-niebezpieczenstwo-dla-litwy.d?id=66231284, 12.03.2015.

President Kaljulaid: Russia does not pose physical threat to Estonia (2017), 27.03.2017, „The Baltic Times”, http://www.baltictimes.com/president_kaljulaid_russia_does_not_pose_physical_threat_to_estonia/, 10.04.2017.

Radczenko A., Kozicz M. (2017), Polskie telewizje na Litwie: Co, kiedy i za ile?, 23.03.2017, Znad Wilii, http://zw.lt/wilno-wilenszczyzna/polskie-telewizjena-litwie-co-kiedy-za-ile/, 4.10.2017. 
Raik K. (2015), Overshadowed by the Russia-West Rift: Security in the Baltic Sea Region, w: Baltic Visions: European Cooperation, Regional Stability, red. K. Redłowska, Foundation Institute for Eastern Studies, Warszawa.

Russia will scoff at Latvia (2016), 6.12.2016, Eurotopics, https:/www.eurotopics.net/ en/167646/latvia-wants-unpatriotic-teachers-dismissed, 10.04.2017.

Societal Security. Inclusion-Exclusion Dilemma. A portrait of the Russian-speaking community in Latvia (2016), red. Ž. Ozolina, Zinātne Publishers.

Survey: Estonians consider migration crisis more dangerous than Russian aggression (2016), 30.03.2016, News.err, http://news.err.ee/v/news/ac71c3f7-1c13-4f9aa6ff-119a780e193e/survey-estonians-consider-migration-crisis-more-dangerous-than-russian-aggression, 30.09.2016.

Szymański P. (2015), Między kontynuacja a adaptacja: polityka bezpieczeństwa i sity zbrojne państw baltyckich, „Komentarze OSW”, 24.11.2015, https://www. osw.waw.pl/pl/publikacje/komentarze-osw/2015-11-24/miedzy-kontynuacjaa-adaptacja-polityka-bezpieczenstwa-i-sily, 24.03.2017.

Tautiniu mažumu departamento prie Lietuvos Respublikos Vyriausybès 2016-2018 metu strateginis veiklos planas (2016), Lietuvos Respublikos kultūros ministro.

Tymul V. (2015), Mniejszość polska na Litwie a współczesne konflikty polsko-litewskie, ,Rocznik Instytutu Europy Środkowo-Wschodniej”, nr 13, z. 3.

US Embassy, Vilnius, http://vilnius.usembassy.gov/news-events/notice-of-fundingopportunity.html, 22.12.2015.

W Polsce i krajach baltyckich - szpice NATO (2014), 5.09.2014, Znad Wilii, http:// zw.lt/litwa/w-polsce-krajach-baltyckich-szpice-nato/, 11.08.2016.

Zięba R. (2014), Międzynarodowe implikacje kryzysu ukraińskiego, „Stosunki Międzynarodowe - International Relations", nr 2, t. 50.

Zięba R. (2015), Ukraina jako przedmiot rywalizacji między Zachodem a Rosja, „Środkowoeuropejskie Studia Polityczne”, nr 3, DOI 10.14746/ssp.2015.3.1.

Герасимов В. (2013), Ценность науки в предвидении, „Военно-промышленный курьер", 27.02.2013, http://www.vpk-news.ru/articles/14632, 4.04.2017.

Латвия внесла в черный список Кобзона, Валерию и Газманова, 21.07.2014, Delfi.lt, http://ru.delfi.lt/misc/celebrities/latviya-vnesla-v-chernyj-spisok-kobzona-valeriyu-i-gazmanova.d?id=65346066, 18.09.2016.

Центральный банк Российской Федерации, http://www.cbr.ru/Bank-notes_coins/ ?PrtId=plan, 10.04.2017.

\section{Security dilemma in the Baltic states after the Crimea annexation}

\section{Summary}

Security threats related to Russia's revisionism in the Baltic region have been observed since the Russia-Georgia war (2008), but the Baltic states have experienced 
significant challenges as a result of the aggressive policy of Russia in Ukraine and the annexation of Crimea in 2014. Russia is seen as the most influential actor who influences the security in the region. While security challenges in the Baltic states are primarily seen through the prism of the military threat, the Baltic states perceive themselves as being under the pressure Russia is exerting on their political systems, economic, social and cultural cohesion as well as national identities. The objective of the study is to answer the question of how the 'Ukrainian crisis' affects security discourse in the Baltic states and how they are adapting to new security challenges on the national and regional levels. Additionally, the relation (hierarchy) between the regional and national security interests of the Baltic states will be analyzed.

Key words: security, Baltic states, Crimea annexation, Russia 